\title{
The Portfolio Diversification Impact Of A Farmland Real Estate Investment Trust
}

\author{
Marvin J. Painter, University of Saskatchewan, Canada
}

\begin{abstract}
An analysis of Canadian farmland risk and return on investment shows that a Farmland Real Estate Investment Trust (F-REIT) would have been a reasonably good investment over the past 35 years. Investors who desire either low or high risk portfolios would not have benefited from an FREIT investment. However, investors in the medium risk category could have improved the financial performance of their portfolios by including an F-REIT investment. The financial gains from F-REIT result from a level of risk that is lower than REITs and stocks, an expected yield that is greater than for bonds, and a low correlation with other financial asset returns. The benefit for the agricultural market is that F-REITs inject new equity by purchasing land from retiring farmers and leasing to farmers who want to expand. The benefit for the non-farmer investor and institutional investors is improvement in overall portfolio financial performance.
\end{abstract}

Keywords: Farmland Real Estate Investment Trust (F-REIT), stock markets, bonds, REITs, efficient investment, investment portfolio, portfolio performance

\section{INTRODUCTION}

ith the recent worldwide recession, the evaporation of wealth due to declining residential and real
estate values, and the accompanying stock market meltdown, average investors around the world are
open to looking at different investment options for their retirement savings. There has been a flight to safe investments like bonds but safe interest bearing financial assets offer very low interest rates which can barely keep up to inflation inside a tax-deferred retirement account and fall far behind on an after-tax basis. If higher inflation does materialize as expected by many analysts, interest-bearing assets will perform poorly. Over the past 20 years, mutual funds have become the choice investment vehicle because they are managed money where individual investors don't have to make many investment decisions. Diversification and asset allocation have become key words for investors and it has become much easier to achieve international diversification and asset sector flexibility within families of mutual funds. The financial industry can provide not only geographic diversification but also diversification across asset types (treasury bills, bonds, stocks, options, futures, currencies, etc.) and industries or sectors. Choosing the right mix of geographic, industry and sector, and asset types is of key importance in achieving the targeted financial performance over an investment horizon. Real estate represents a significant percentage of world asset value and has been an important component of investment portfolios, either through Real Estate Investment Trusts (REITs) or direct investment in real estate.

Farmland, as a real estate investment asset, is still not widely available to investors because of the lack of liquid, divisible and marketable farmland investment vehicles that trade in well established secondary markets. However, as average farm size grows, farmers are using significantly more leasing to finance land and equipment in their operations. Over 50\% of farmland in Canada and the United States is now leased by farm operators and the demand for leased land is growing as average farm size continues to increase (Painter 2005 and Painter 2006), which points to a growing demand for farmland investors. But so far, there is no easy way for investors to invest in farmland. There are very few farmland real estate investment trusts (F-REITs) available in the world that offer liquidity and marketability like bonds, REITs, or stock markets. And even if a liquid and marketable farmland investment vehicle was available, the average investor needs to know whether farmland is a good mix in their portfolios. What are the risk-return characteristics of an F-REIT and what is the impact on portfolio performance when an F-REIT is added to the portfolio? In this paper, a diversified Canadian F-REIT is assessed to determine its impact on the financial performance of a well-diversified international portfolio. 


\section{BACKGROUND}

Markowitz (1959) introduced the concept of efficient portfolios, where assets were considered for portfolios based not only on their individual expected returns and risk but on how their returns were correlated with other assets. The most important conclusion from Markowitz was that the total risk of a portfolio will almost always be less than the sum of the risks of the individual assets held. Tobin (1958) and Treynor (1961) introduced the twofund separation theorem by including the risk-free asset in the mix, producing the Capital Market Line (CML). This simplified the investment decision as all efficient portfolios were some combination of the tangency portfolio (market portfolio) and the risk-free asset. Investors needed only to choose what percentage they wanted invested in safe risk-free assets and what percentage in the risky market portfolio. CML Efficient investment portfolios were those that provided the highest return for a chosen level of risk, or conversely, the lowest risk for a chosen level of return. It was found that portfolios always dominated individual assets, providing a higher return for a chosen level of risk. This led to the development of the Capital Asset Pricing Model (CAPM) by Sharpe (1964), which suggested that investors should only be concerned about that portion of an asset's risk that adds to the total risk of a welldiversified portfolio, called systematic risk, as opposed to the portion of the asset's risk that is diversified away when included in the portfolio. An asset could have a high total risk level, but if most of that risk is diversified away within an efficient portfolio, then it would add little risk to the overall portfolio and would be considered a low-risk asset.

Figure 1 illustrates the concept of efficient investment. The efficient frontier (Markowitz) represents all those investments that dominate on a risk-return basis when the risk-free asset is not included in the mix. The curved efficient frontier is made up mostly of portfolios because combining assets into portfolios allows risk reduction without necessarily reducing return. When the risk-free asset is added to the choice set, the Capital Market Line (Tobin and Treynor) becomes the efficient set of investment opportunities, where every investment on the CML is a combination of the risk-free asset and the tangency portfolio. To maximize utility, investors mix the risk-free asset and the market (tangency) portfolio to achieve their desired level of risk, which maximizes the expected return for that chosen level of risk. However, in Figure 1 and in this study, the borrowing rate for investors is also added, which means there are two tangency portfolios. The CML (heavy line) is slightly kinked as the borrowing rate is higher than the risk-free lending rate and a small part of the concave efficient frontier is a segment of the CML.

Figure 1: Efficient Investment and the Capital Market Line

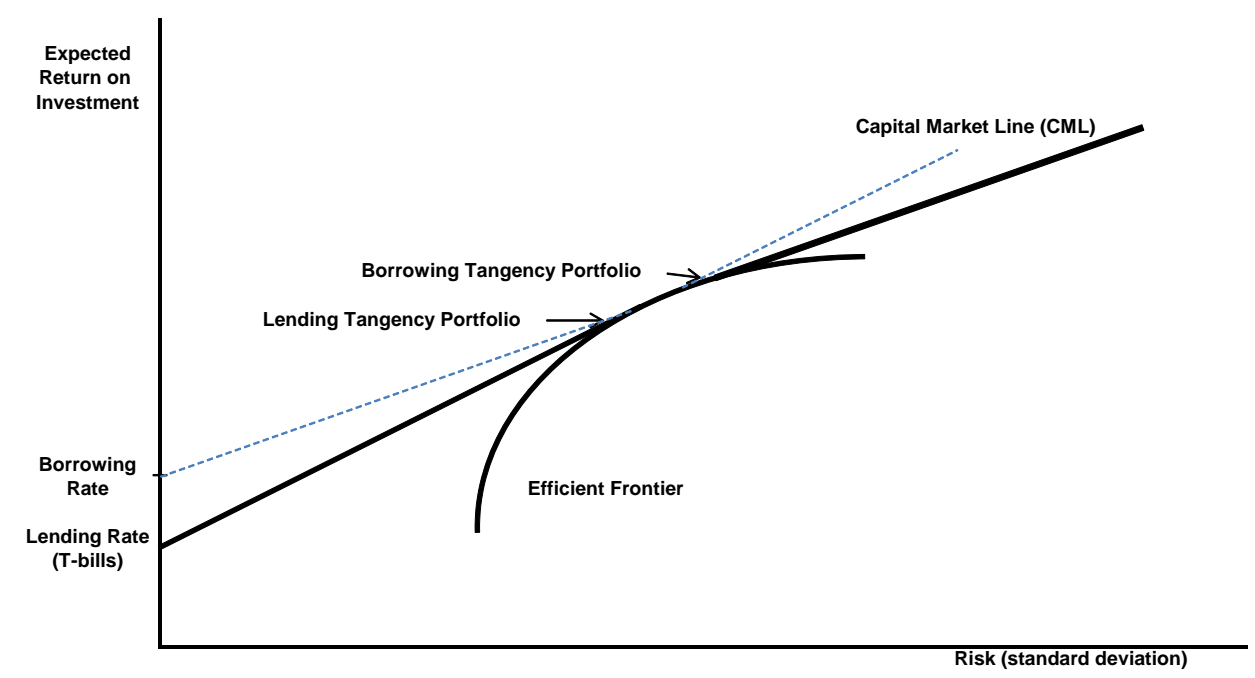

A number of studies have been done that assess the risk level and portfolio investment quality of farmland. Peter Barry (1980) applied the CAPM to farmland in eleven different regions in the United States and found that farmland added very little risk to a diversified portfolio of stocks and bonds because most of farmland risk is 
diversifiable (unsystematic risk). Kaplan (1985) found that farm real estate had two favorable attributes: high total return and low correlation with other assets, which meant that including farmland in a portfolio added a high return asset with very little risk added. Moss, Featherstone and Baker (1987) as well as Lins, Kowalski and Hoffman (1992) and Ruebens and Webb (1995), assessed efficient portfolios using US financial assets and farmland and concluded that the addition of farmland to stock and bond portfolios improved portfolio performance. Painter (2000) assessed whether Saskatchewan farmland could improve portfolio performance, where the choice set of assets includes stock markets from the G7 countries, Canadian bonds and treasury bills, and Saskatchewan farmland. He found that farmland improved portfolio performance, especially at medium levels of risk. Bigge and Langemeier (2004) found that Kansas farmland's low level of systematic risk meant that farmers could improve overall portfolio performance with investment in the stock market. Libbin, Kohler and Hawkes (2004) suggest that farmers could improve financial performance by investing in financial assets and/or paying down their debt liabilities. Painter (2006) found that the financial gains from Canadian farmland investment result from a low level of risk with an expected yield that is greater than for bonds and low correlation with other financial asset returns. Painter and Eves (2008) assessed farmland investments in United States, Canada, New Zealand and Australia and found that the low and negative correlation of farmland yields with stocks and bonds made it a good candidate for portfolio diversification. These studies suggest that both farmer and non-farmer investors could potentially improve their long-term financial performance by diversifying farmland and financial assets in their investment portfolios.

\section{THE EXPECTED VALUE-VARIANCE (E-V) MODEL}

An E-V model is used to assess whether a Canadian farmland real estate investment trust (F-REIT) would enhance the financial performance of a diversified portfolio of financial assets, including REITs. The E-V model is used to derive the efficient set of investments by minimizing risk for various expected return constraints. The mapping of the minimum risk and corresponding return combinations provides the efficient set or frontier. The E-V model is as follows:

$\underset{\mathrm{X}}{\operatorname{Minimize}} \mathrm{X}^{\prime} \mathrm{Q} \mathrm{X}$

$\mathrm{X}$

subject to:

$$
\begin{aligned}
& R_{p}=C^{\prime} X \\
& 1.0=1^{\prime} X
\end{aligned}
$$

where:

$\mathrm{X} \quad=$ vector of the wealth share invested in each asset, $\mathrm{x}_{\mathrm{i}}$ being the proportion of total wealth invested in asset $\mathrm{i}$

$\mathrm{Q} \quad=$ variance-covariance matrix of asset returns, $\operatorname{Cov}\left(\mathrm{r}_{\mathrm{i}}, \mathrm{r}_{\mathrm{j}}\right)$

$\mathrm{R}_{\mathrm{p}} \quad=$ portfolio return on investment

$\mathrm{C}=\mathrm{Nx} 1$ vector of expected return on investment for $\mathrm{N}$ choice assets

The E-V model is based on a concave investment opportunity surface (Markowitz efficient frontier). However, the inclusion of the risk-free asset changes the investment opportunity surface to a straight line, the CML, which is a linear combination of the risk-free asset and the point of tangency with the concave investment opportunities surface. The greater is the slope of the CML, the better the investment performance (return per unit of risk) for all levels of risk greater than zero. This E-V model is used to calculate the CML from the set of choice assets, both with and without farmland included in the choice set, to determine whether financial performance is enhanced with the addition of farmland.

\section{CALCULATING F-REIT AND FINANCIAL ASSET RETURNS}

Financial returns are calculated for each of the choice assets for the study period 1972-2008. The choice set of assets includes T-bills, long term bonds, Canadian Farmland Real Estate Investment Trust (F-REIT), United States REITs, and stock markets in Australia, Canada, Japan, United States, Europe, Hong Kong, and the World Stock Market Portfolio. For T-bills and bonds, average annual Canadian yields are calculated while for stock 
markets, average annual dividend, capital gain and total yields are calculated, using Morgan Stanley International stock market data ${ }^{1}$. Average annual income and capital gain yields are calculated for REITs ${ }^{2}$ and a Canadian FREIT.

\section{Calculating Income and Capital Gain Yields on a Canadian F-REIT}

The total return to an F-REIT is divided into two parts; income return and capital gain return. The income return is based on the net lease revenue obtained from renting the farmland in the trust to farm operators. The capital gain return is the change from year to year in the market value of the land.

The income return to Canadian farmland in the trust is calculated using an average net lease value that could be obtained by a farmland owner for leasing their land ${ }^{3}$. The method used in this study is based on the standard crop share approach, where the F-REIT receives a percentage of the gross revenues produced (20\% of total revenue is used to calculate the gross lease revenue to the farmland owner ${ }^{4}$ ). The F-REIT is then responsible for paying property taxes and building depreciation to arrive at a net lease amount or income return to the F-REIT. Hence, the annual income return per acre to farmland ownership in a Canadian F-REIT is calculated as follows;

$\mathrm{IR}_{\mathrm{t}}=\mathrm{LR}_{\mathrm{t}}-\mathrm{PT} \mathrm{T}_{\mathrm{t}}-\mathrm{BD}_{\mathrm{t}}$

where,

$\mathrm{IR}_{\mathrm{t}} \quad=$ income return to farmland per acre in year $\mathrm{t}$;

$\mathrm{LR}_{\mathrm{t}} \quad=$ gross lease revenue per acre in year $\mathrm{t}(17.5 \%$ of Gross Farm Revenues);

$\mathrm{PT}_{\mathrm{t}} \quad=$ property taxes per acre in year $\mathrm{t}$;

$\mathrm{BD}_{\mathrm{t}} \quad=$ building depreciation ${ }^{5}$ per acre in year $\mathrm{t}$;

The annual income and capital gain yields for a Canadian F-REIT are calculated as follows:

$\mathrm{IY}_{\mathrm{t}} \quad=\frac{I R_{t}}{V_{t-1}}$

where,

$\mathrm{IY}_{\mathrm{t}}=$ income yield (income return on investment) per acre in year $\mathrm{t}$;

$\mathrm{IR}_{\mathrm{t}} \quad=$ income return to farmland per acre in year $\mathrm{t}$;

$\mathrm{V}_{\mathrm{t}-1}=$ average farmland value per acre in year $\mathrm{t}-1$.

$\mathrm{CGY}_{\mathrm{t}}=\frac{V_{t}-V_{t-1}}{V_{t-1}}$

where,

$\mathrm{CGY}_{\mathrm{t}}=$ capital gain yield (capital gain return on investment) per acre in year $\mathrm{t}$;

$\mathrm{V}_{\mathrm{t}}, \mathrm{V}_{\mathrm{t}-1}=$ average farmland values per acre in years $\mathrm{t}$ and $\mathrm{t}-1$, respectively.

\footnotetext{
${ }^{1}$ Morgan Stanley Capital International (MSCI Barra): http://www.mscibarra.com

${ }^{2}$ The data source for US REITs is FTSE NAREIT US Real Estate Index Series (All Publicly Traded REITs 1972-2009): http://www.reit.com

${ }^{3}$ Canadian farmland returns are an average of the returns in the five major agriculture producing provinces: Alberta,

Saskatchewan, Manitoba, Ontario and Quebec.

${ }^{4} 17.5 \%$ is a common crop share arrangement in North America, which compares closely with cash rents that are usually in the $5 \%-7 \%$ of land values range.

${ }^{5}$ The value of farmland includes the value of farm buildings which means that building depreciation is an expense associated with farmland ownership.
} 
The annual total investment yield for the F-REIT, or total return on investment (ROI), is the sum of the income and capital gain yields, calculated as follows

$\mathrm{ROI}_{\mathrm{t}}=\frac{I R_{t}}{V_{t-1}}+\frac{V_{t}-V_{t-1}}{V_{t-1}}$

Tax and Management Expense Adjustments to F-REIT and Bond Investment Yields

Before an efficient frontier of investments can be assessed, it must be recognized that there are tax differences between various financial assets and F-REITs and adjustments must be made to account for these differences. Also, an F-REIT requires management so a Management Expense Ratio (MER) must be included to account for management costs.

The first tax adjustment is to the F-REIT income return (net lease revenue earned). The F-REIT must pay corporate taxes on net lease income before any distributions to unit holders can be made, just as a stock market company must pay corporate taxes before distributing dividends. An average Canadian corporate tax rate of $30 \%$ is used to adjust the income return in the F-REIT (After Tax Income Return = Income Return x .70). The second tax adjustment is to T-bill and Long Bond yields. In Canada, the average personal tax rate on interest is significantly higher than on dividends or capital gains, which means that to an average investor, a 5\% pre-tax dividend or capital gain yield is significantly better than a $5 \%$ pre-tax bond yield, because the bond interest will attract higher taxes. Since the study is using before-tax average yields, a discount must be applied to T-bills and Long Bonds to adjust for the higher rates of taxation. This is not an adjustment for risk but recognizes that interest is taxed significantly higher and thus has less value to an investor on an after-tax basis. The average tax adjustment factor is calculated as follows:

$\mathrm{T}=\frac{1-t_{\text {interest }}}{1-t_{\text {Dividend,CG }}}$

where,

$\mathrm{T}=\quad=$ the tax adjustment factor for average T-bill and Long Bond yields;

$\mathrm{t}_{\text {interest }}=$ the average personal tax rate on interest income;

$\mathrm{t}_{\text {Dividend,CG }}=$ the average personal tax rate on dividend and capital gain income.

Using average 2008 personal tax rates in Canada, the adjustment factor $\mathrm{T}$ is $74.5 \%$. Therefore, average $\mathrm{T}$ bill and Long Bond yields are discounted to $74.5 \%$ of their calculated values to adjust for the fact that interest income is taxed higher than dividend and capital gain income.

An MER of 3\% has been subtracted from the calculated F-REIT average yield to account for management expenses. A typical Canadian MER for equity funds such as Templeton Franklin, AIM Trimark, Investors Group and others is between $2 \%$ and $3 \%$. Since an F-REIT would require active management, the upper end (3\%) was chosen as a reasonable estimate.

\section{DISCUSSION OF RESULTS}

Table 1 provides average annual investment yields for the choice set of assets. These results include all the tax adjustments and the F-REIT MER deduction. The risk and return characteristics of F-REIT show similarities with stock markets in that income yields and risk on F-REIT are very similar to dividend yields and risk on stock markets. However, capital gain yields and risk on F-REIT are lower than for stocks, putting the total yield and risk on F-REIT in between bonds and stocks. REITs stand out because the entire yield has been income yield. Also, the risk level associated with the income yield on REITs is higher than for dividends while the risk level associated with REIT price movements is slightly lower than the price risk for stock markets. The investment attraction of F-REIT 
appears to be reasonable investment yield with relatively low risk, as indicated by the lower coefficient of variation (risk per unit of return) on F-REIT than on stocks and REITs.

Table 1: Average Annual Investment Yields for T-bills, Long Bonds, F-REIT, REITs and Stock Markets (1972 - 2008)

\begin{tabular}{|c|c|c|c|c|c|c|c|}
\hline & \multicolumn{2}{|c|}{ Income/Div Yield } & \multicolumn{2}{|c|}{ Cap Gain Yield } & \multicolumn{2}{|l|}{$\underline{\text { Total Yield }}$} & \multirow{2}{*}{$\begin{array}{l}\text { Coefficient } \\
\text { Of Variation }\end{array}$} \\
\hline & Avg Yield & $\underline{\text { Std Dev }}$ & Avg Yield & $\underline{\text { Std Dev }}$ & Avg Yield & $\underline{\text { Std Dev }}$ & \\
\hline T-bills & N/A & $\mathrm{N} / \mathrm{A}$ & N/A & N/A & $5.3 \%$ & $0.0 \%$ & N/A \\
\hline Long Bonds & N/A & N/A & N/A & N/A & $6.2 \%$ & $2.8 \%$ & 0.45 \\
\hline Borrowing $^{6}$ & N/A & N/A & N/A & N/A & $8.0 \%$ & $0.0 \%$ & N/A \\
\hline \multicolumn{8}{|l|}{ Real Estate: } \\
\hline F-REIT & $2.8 \%$ & $0.7 \%$ & $7.4 \%$ & $9.1 \%$ & $7.2 \%^{7}$ & $9.5 \%$ & 1.36 \\
\hline REITs & $8.9 \%$ & $2.8 \%$ & $-0.2 \%$ & $20.4 \%$ & $8.6 \%$ & $21.9 \%$ & 2.54 \\
\hline \multicolumn{8}{|c|}{ Stock Markets: } \\
\hline Canada & $2.6 \%$ & $1.0 \%$ & $5.9 \%$ & $21.5 \%$ & $8.4 \%$ & $21.9 \%$ & 2.61 \\
\hline Australia & $3.2 \%$ & $1.0 \%$ & $5.1 \%$ & $25.1 \%$ & $8.2 \%$ & $25.9 \%$ & 3.16 \\
\hline US & $2.4 \%$ & $1.1 \%$ & $5.7 \%$ & $18.3 \%$ & $8.1 \%$ & $18.7 \%$ & 2.31 \\
\hline Japan & $1.2 \%$ & $0.8 \%$ & $7.9 \%$ & $34.1 \%$ & $9.1 \%$ & $34.6 \%$ & 3.80 \\
\hline Europe & $3.0 \%$ & $1.0 \%$ & $6.5 \%$ & $22.1 \%$ & $9.5 \%$ & $22.7 \%$ & 2.39 \\
\hline World & $2.3 \%$ & $0.9 \%$ & $5.9 \%$ & $18.4 \%$ & $8.2 \%$ & $18.8 \%$ & 2.29 \\
\hline Hong Kong & $4.2 \%$ & $1.7 \%$ & $8.6 \%$ & $46.6 \%$ & $12.7 \%$ & $47.9 \%$ & 3.77 \\
\hline
\end{tabular}

The other attraction of F-REIT is its low and/or negative correlation with bonds, stocks, and REITs, which gives it significant diversification advantages for an investment portfolio ${ }^{8}$. Table 2 illustrates the correlation coefficients between the choice assets.

Table 2: Correlation Matrix for the Choice Set of Assets (1972 - 2008)

\begin{tabular}{|l|l|l|l|l|l|l|l|l|l|l|l|}
\hline & T-b & L B & F-REIT & REIT & Can & Aus & US & Japan & Europe & World & HK \\
\hline T-bills & 1.0 & .84 & .18 & .11 & -.34 & -.31 & .03 & .15 & -.21 & -.25 & .10 \\
\hline L Bonds & & 1.0 & .03 & .16 & -.08 & -.03 & .18 & .13 & .06 & .15 & .03 \\
\hline F-REIT & & & 1.0 & -.11 & -.05 & -.09 & -.14 & -.16 & -.22 & -.22 & -.01 \\
\hline REITs & & & & 1.0 & .45 & .50 & .55 & .17 & .38 & .49 & .42 \\
\hline Can & & & & & 1.0 & .74 & .64 & .46 & .60 & .71 & .57 \\
\hline Aus & & & & & & 1.0 & .58 & .47 & .68 & .75 & .63 \\
\hline US & & & & & & & 1.0 & 34 & .74 & .85 & .51 \\
\hline Japan & & & & & & & & 1.0 & .46 & .65 & .58 \\
\hline Europe & & & & & & & & & 1.0 & .86 & .50 \\
\hline World & & & & & & & & & & & 1.0 \\
\hline HK & & & & & & & & & & & .61 \\
\hline
\end{tabular}

The combination of reasonable return, low total risk and low correlation makes F-REIT attractive for an internationally diversified investment portfolio. Applying the E-V model to the choice set of assets produces the efficient portfolios and Capital Market Line (CML). Figure 2 illustrates the two kinked CML's and shows that there would have been some improvement in portfolio performance over the study period had F-REIT been included. The CML (F-REIT included) shows that in the medium risk category, higher returns for each level of risk could have been achieved with F-REIT as part of the portfolio.

\footnotetext{
${ }^{6}$ The borrowing rate is the average prime rate plus $2 \%$, adjusted by the interest tax factor of $74.5 \%$.

${ }^{7}$ Income Yield after corporate tax + Capital Gain Yield - 3.0\% MER: $(2.8 \%+7.4 \%-3.0 \%=7.2 \%)$

${ }^{8}$ It is important to note that the low risk and negative correlation is based on F-REIT (a portfolio of farmland in Canada) and does not necessarily represent the risk and correlation of individual farmland assets.
} 
Figure 2: The Capital Market Line with and without F-REIT Included (1972 - 2008)

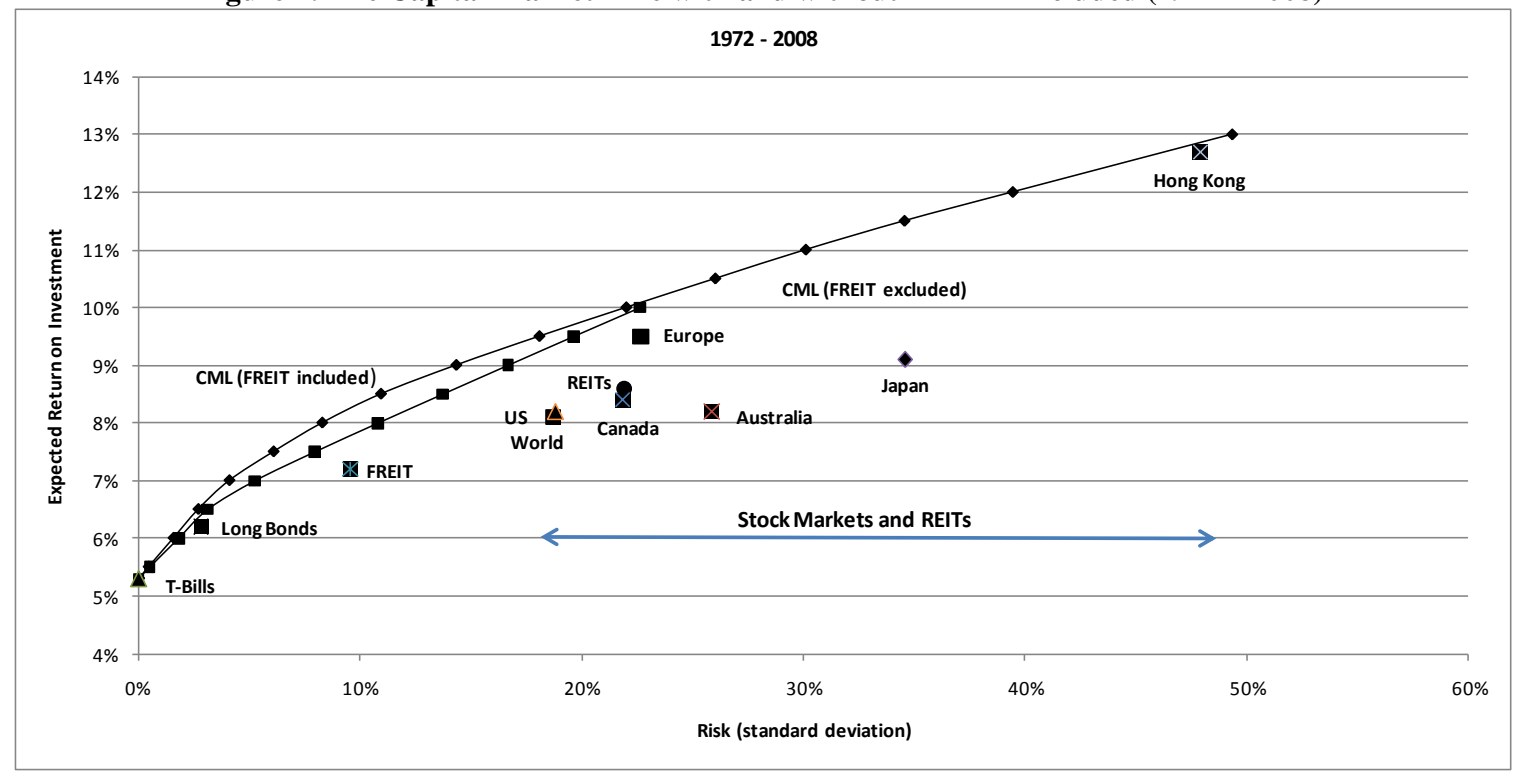

Table 3 provides a comparison of the portfolio compositions between the two CML's. The inclusion of FREIT in the choice set has an impact on medium risk portfolio performance but has no significant impact on the low or high risk portfolios. In the $6 \%$ and $10 \%$ expected return portfolios, F-REIT does very little in terms of reducing risk. However, in the $8 \%$ expected return portfolio, there is almost $25 \%$ risk reduction by including F-REIT in the choice set of assets.

It appears that the biggest advantage of F-REIT is at the risk level where many investors choose to be. The average stock market portfolio (World portfolio, US stocks) usually has a standard deviation of $18 \%-20 \%$. When average investors combine stocks, bonds and real estate, they might typically end up with a portfolio risk level of $10 \%-15 \%$, which is where F-REIT can increase financial performance. Low risk portfolios are dominated by Tbills and Long Bonds and neither REITs nor F-REIT have low enough risk levels to enter these portfolios. As investors are willing to increase risk for a higher expected return, F-REIT, as opposed to REITs and stocks, gradually replaces Long Bonds in the efficient portfolios in the medium risk category. Investors looking for low risk-low return or high risk-high return portfolios will likely not be interested in F-REIT.

Table 3: Comparison of Efficient Portfolios with and without F-REIT Included (1972-2008)

\begin{tabular}{|c|c|c|c|}
\hline Expected Return on Investment & $6 \%$ & $8 \%$ & $10 \%$ \\
\hline \multicolumn{4}{|l|}{ Risk (standard deviation): } \\
\hline F-REIT included & $1.6 \%$ & $8.3 \%$ & $22.0 \%$ \\
\hline F-REIT excluded & $1.8 \%$ & $10.8 \%$ & $22.6 \%$ \\
\hline \multicolumn{4}{|c|}{ Portfolio Composition F-REIT included: } \\
\hline T-bills & $48.0 \%$ & $0.0 \%$ & $0.0 \%$ \\
\hline Long Bonds & $39.2 \%$ & $3.8 \%$ & $0.0 \%$ \\
\hline F-REIT & $8.8 \%$ & $59.3 \%$ & $19.5 \%$ \\
\hline REITs & $0.5 \%$ & $10.4 \%$ & $5.8 \%$ \\
\hline \multirow[t]{2}{*}{ Stocks } & $3.5 \%$ & $26.5 \%$ & $74.7 \%$ \\
\hline & $100 \%$ & $100 \%$ & $100 \%$ \\
\hline \multicolumn{4}{|c|}{ Portfolio Composition F-REIT excluded: } \\
\hline T-bills & $39.9 \%$ & $0.0 \%$ & $0.0 \%$ \\
\hline Long Bonds & $55.8 \%$ & $51.7 \%$ & $0.0 \%$ \\
\hline F-REIT & $0.0 \%$ & $0.0 \%$ & $0.0 \%$ \\
\hline REITs & $0.0 \%$ & $12.7 \%$ & $24.4 \%$ \\
\hline \multirow[t]{2}{*}{ Stocks } & $4.3 \%$ & $35.6 \%$ & $75.6 \%$ \\
\hline & $100 \%$ & $100 \%$ & $100 \%$ \\
\hline
\end{tabular}




\section{CONCLUSIONS}

Can investors improve financial performance by adding a farmland real estate investment trust to their investment portfolios? This study shows that for the period $1972-2008$, financial performance was significantly improved with the addition of F-REIT. A Canadian F-REIT is considered relatively low risk, enters the efficient portfolios at low to medium risk levels and adds the most financial improvement to medium risk portfolios. Compared to T-bills and Long Bonds, the F-REIT has higher risk and yield. Compared with REITs, the F-REIT has significantly lower income yields and higher capital gain yields, totaling slightly lower total yields, but significantly lower risk. Compared with stocks, F-REIT has income yields that are similar to dividend yields on stocks and capital gain yields that are usually lower, on average, than stocks. However, the total risk for an F-REIT is much lower than the risk for stocks. The low and negative correlation of F-REIT yields with bonds, REITs and stocks make it a good candidate for portfolio diversification benefits.

What are the implications for investors? For current farmland investors, especially farmers, it implies that they should own REITs, stocks and bonds to complement their farmland investment holdings. Farmers might consider leasing instead of buying more farmland when they expand (this is already happening as observed by the high proportion of farmland that is leased in Canada and the US). For institutional investors, it implies that there should be consideration of organizing and operating F-REITs as part of the overall family of funds that are made available to their retail investor clients. Large pension funds should consider the diversification benefits of holding F-REITs as part of their portfolios. For average retail investors, it implies that they should consider outright purchase of farmland or seek a farmland investment vehicle such as an F-REIT. Outright purchase of farmland has many drawbacks such as having to manage the lease, less liquidity than financial assets and lumpiness of the asset units (usually farmland is sold in parcels of 80 or 160 acres, making the total purchase price quite high). F-REITs are beginning to appear ${ }^{9}$ that provide management, asset divisibility and liquidity, which makes investing in farmland much easier. The benefit for the agricultural market is that F-REITs inject new equity by purchasing land from retiring farmers and leasing to farmers who want to expand. The benefit for the non-farmer investor and institutional investors is improvement in overall portfolio financial performance.

\section{AUTHOR INFORMATION}

Dr. Painter is Head of the Department of Management and Marketing and a scholar in the W. Brett Wilson Centre for Entrepreneurial Excellence. The centre provides entrepreneurship minors in a number of colleges at the University of Saskatchewan, conducts research in entrepreneurship and innovation, and offers outreach entrepreneurial training and services. Dr. Painter's currently teaches in the MBA, Masters in Professional Accounting (MPACC), undergraduate business, and in the entrepreneurship minors offered by the Wilson Centre.

\section{REFERENCES}

1. Agriculture and Agri-Food Canada, Canadian Agricultural Statistics, Federal Department of Agriculture, Government of Canada. (http://www.agr.gc.ca/index_e.php)

2. Bank of Canada, National Financial Statistics. (http://www.bank-banque-canada.ca/en/index.html)

3. Barry, Peter J. (1980). "Capital Asset Pricing and Farm Real Estate" American Journal of Agricultural Economics. 62: 549-63

4. Bigge, Holly M., and Michael R. Langemeier (2004). "Relative Profitability and Risk of Kansas Farms and the S\&P 500." Journal of the American Society of Farm Managers and Rural Appraisers. American Society of Farm Managers and Rural Appraisers (2004 Journal of ASFMRA). 57-63.

5. $\quad$ Kaplan, Howard M (1985). "Farmland as a Portfolio Investment." The Journal of Portfolio Management. Volume 11: 73-79.

\footnotetext{
${ }^{9}$ An example is Agriculture Development Corporation in Canada, which has launched a series of limited partnerships to facilitate investments in diversified portfolios of Saskatchewan farmland.
} 
6. Libbin, James D., Jeremy D. Kohler, and Jerry M. Hawkes (2004). "Financial and Real Estate Investments in Mixed-Asset Agricultural Portfolios". Journal of the American Society of Farm Managers and Rural Appraisers. American Society of Farm Managers and Rural Appraisers (2004 Journal of ASFMRA). 97107.

7. Libbin, James D., Jeremy D. Kohler, and Jerry M. Hawkes (2004). "Does Modern Portfolio Theory Apply to Agricultural Land Ownership? Concepts for Farmers and Farm Managers". Journal of the American Society of Farm Managers and Rural Appraisers. American Society of Farm Managers and Rural Appraisers (2004 Journal of ASFMRA). 85-96.

8. Lins, D., A. Kowalski, and C. Hoffman (1992). "Institutional Investment Diversification: Foreign Stocks vs U.S. Farmland." In Proceedings of Regional Research Committee NC-161, Department of Agricultural Economics, Kansas State University, Manhatten, Kansas. February.

9. Markowitz, H. M.(1959). Portfolio Selection: Efficient Diversification of Investment. New York: John Wiley and Sons.

10. Moss, Charles B., Allen M. Featherstone, and Timothy G. Baker (1987). "Agricultural Assets in an Efficient Multi-Period Investment Portfolio." Agricultural Finance Review. 47: 82-94

11. Painter, Marvin J. (2000). "Should Saskatchewan Farmland be Part of Your Investment Portfolio?". Canadian Journal of Agricultural Economics, Canadian Agricultural Economics and Farm Management Society. Volume 48, 39-50, April 2000.

12. Painter, Marvin J. (2005). "A Comparison of Farm Incomes and Wealth in Canada" Journal of International Farm Management. Journal of the International Farm Management Association. Volume 3, Edition 1 (on-line journal). (http://ifmaonline.org)

13. Painter, Marvin J. (2006). "The Financial Benefits of a Canadian Farmland Mutual Fund" Journal of the American Society of Farm Managers and Rural Appraisers. American Society of Farm Managers and Rural Appraisers. Vol. 69, No. 1, Pages 40 - 48. October 2006.

14. Painter, Marvin J. and Chris Eves (2008). "The Financial Gains from Adding Farmland to an International Investment Portfolio" Journal of Real Estate Portfolio Management, American Real Estate Society, California State University. Vol. 14, Number 1, Pages 63-73. March 2008.

15. Ruebens, J and Webb, J. (1995). Farmland as an Inflation Hedge. Real Estate Research Issues. No. 2, 129134.

16. Statistics Canada, National and International Statistics. (http://www.statcan.ca/menu-en.htm)

17. Tobin, James (1958). "Liquidity Preference as Behavior Toward Risk," Review of Economic Studies, XXVI, February, 65-86.

18. Treynor, J. (1961). "Towards a Theory of the Market Value of Risky Assets," unpublished manuscript. 
NOTES 